\title{
Rasio Neutrofil Limfosit untuk Membedakan Meningitis Bakterial dan Viral pada Anak
}

\author{
Ismi Ratnasari, Fadhilah Tia Nur, Muhammad Riza \\ Bagian Ilmu Kesehatan Anak Fakultas Kedokteran Universitas Sebelas Maret/RSUD Dr. Moewardi, Surakarta
}

\begin{abstract}
Latar belakang. Meningitis bakterial merupakan penyakit infeksi yang berat pada meningen (selaput otak) yang menimbulkan mortalitas dan morbiditas yang tinggi di dunia. Gejala dan tanda kinis tidak dapat digunakan untuk membedakan antara meningitis bakterial dan miningitis viral. Apabila pemeriksaan cairan serebrospinal tidak memungkinkan untuk dilakukan, pemeriksaan marker inflamasi serum dapat dilakukan untuk menunjang diagnosis dari meningitis. Rasio neutrofil limfosit (NLR) adalah parameter sederhana yang dapat digunakan untuk membedakan meningitis bakterial dan viral.

Tujuan. Membedakan nilai NLR antara meningitis bakterial dan meningitis viral pada anak.

Metode. Penelitian potong lintang dengan pendekatan uji diagnostik. Data didapatkan dari rekam medis pasien dengan meningitis usia 1 bulan - 18 tahun yang dirawat di RSUD Dr. Moewardi Januari 2017 - Desember 2020. Data dianalisis menggunakan uji independent $t$ test dan uji Mann Whitney, tingkat kemaknaan hasil uji ditentukan berdasarkan nilai $\mathrm{p}<0,05$.

Hasil. Dari 36 rekam medis, meningitis bakterial dan viral paling banyak terjadi pada usia 1 bulan - 5 tahun. Dari data karakteristik tidak didapatkan perbedaan yang bermakna. Terdapat perbedaan bermakna NLR pada pasien meningitis bakterial dan viral tanpa disertai infeksi di luar sistem saraf pusat $(\mathrm{p}=0,014)$. Nilai cut off NLR untuk meningitis bakterial adalah $>2,31$ dengan sensitivitas $81,8 \%$, spesifisitas $71,4 \%$. Kesimpulan. Rasio neutrofil limfosit dapat digunakan untuk membedakan meningitis bakterial dan viral dengan nilai cut off untuk meningitis bakterial adalah $>2,31$. Sari Pediatri 2021;23(4):222-7
\end{abstract}

Kata kunci: meningitis bakterial, meningitis viral, rasio neutrofil limfosit, anak

\section{Neutrophil Lymphocyte Ratio to Differentiate Bacterial and Viral Meningitis in Children}

Ismi Ratnasari, Fadhilah Tia Nur, Muhammad Riza

Background. Bacterial meningitis is a serious infectious disease of the meninges which causes high mortality and morbidity in the world. Clinical signs and symptoms cannot be used to differentiate between bacterial meningitis and viral miningitis. If examination of the cerebrospinal fluid is not possible, serum inflammation markers can be examined to support the diagnosis of meningitis. The lymphocyte neutrophil ratio (NLR) is a simple parameter that can be used to differentiate bacterial and viral meningitis.

Objective. To differentiate NLR values between bacterial meningitis and viral meningitis in children.

Methods. A cross-sectional study with a diagnostic test approach. Data obtained from the medical records of patients with meningitis aged 1 month - 18 years who were treated at Dr. Moewardi January 2017 - December 2020. Data were analyzed using the independent $t$ test and the Mann Whitney test, the level of significance of the test results was determined based on $\mathrm{p}$ value $<0.05$.

Result. Among the 36 medical records, bacterial and viral meningitis mostly occurred at the age of 1 month - 5 years. From the characteristic data, there was no significant difference. There was a significant difference in NLR in bacterial and viral meningitis patients without infection outside the central nervous system $(\mathrm{p}=0.014)$. The NLR cut off value for bacterial meningitis was $>2.31$ with sensitivity of $81.8 \%$, specificity of $71.4 \%$.

Conclusion. The NLR can differentiate between bacterial and viral meningitis with cut-off value for bacterial meningitis $>2.31$. Sari Pediatri 2021;23(4):222-7

Keywords: bacterial meningitis, viral meningitis, lymphocyte neutrophil ratio, children

Alamat korespondensi: Ismi Ratnasari. Departemen Ilmu Kesehatan Anak Fakultas Kedokteran Universitas Sebelas Maret/RSUD Dr. Moewardi Surakarta, Gedung Anggrek Lantai 4, Jl. Kolonel Sutarto No.132, Jebres, Kota Surakarta, Jawa Tengah 57126. Email: ismicp1988@gmail.com 
Ismi Ratnasari dkk: Rasio neutrofil limfosit untuk membedakan meningitis bakterial dan viral pada anak

M eningitis adalah penyakit pada sistem saraf pusat akibat inflamasi dari meningen (selaput otak) yang menimbulkan mortalitas dan morbiditas yang tinggi di dunia. Inflamasi pada meningen dapat disebabkan oleh infeksi virus, bakteri atau mikroorganisme lainnya. Meningitis bakterial merupakan penyakit infeksi yang berat pada meningen. ${ }^{1-3}$

Patogenesis meningitis melibatkan beberapa mediator inflamasi. Lipopolisakarida dinding sel bakteri Gram negatif atau asam teikhoid, peptidoglikan dinding sel bakteri Pneumococcus menstimulasi respon inflamasi lokal melalui produksi TNF, interleukin 1, prostaglandin E dan mediator inflamasi lainnya. Respon inflamasi tersebut ditandai dengan infiltrasi neutrofil, peningkatan permeabilitas kapiler, perubahan sawar darah otak, dan trombosis vaskuler. ${ }^{4}$ Pada meningitis, infiltrasi bakteri dalam cairan LCS menstimulasi produksi TNF, IL-1, dan mediator inflamasi lainnya seperti IL-6, IL-8, platelet-activating factor, nitrit oksida, metabolik asam arakhidonik seperti prostaglandin dan prostasiklin. Sitokin-sitokin tersebut mengaktivasi adhesion-promoting receptor pada sel endotel vaskuler serebral dan leukosit, dan menstimulasi infiltrasi neutrofil ke tempat peradangan. Leukosit melakukan penetrasi ke endotel kapiler dan mengeluarkan produk proteolitik dan radikal oksigen toksik. ${ }^{5}$

Ada beberapa biomarker untuk mendiagnosis infeksi bakterial, seperti $c$-reactive protein (CRP), prokalsitonin (PCT), CD64 pada leukosit darah tepi. Akan tetapi, pemeriksaan tersebut memerlukan alat khusus dan harga yang mahal. Pemeriksaan marker inflamasi lainnya, seperti immunoassay memerlukan biaya yang mahal dan proses yang rumit. ${ }^{6}$ Rasio neutrofil limfosit (NLR) merupakan perbandingan jumlah neutrofil terhadap limfosit. Rasio neutrofil limfosit adalah parameter sederhana yang dapat digunakan untuk mendiagnosis secara mudah adanya inflamasi. Kelebihan marker tersebut adalah sederhana dan murah. ${ }^{7-9}$ Rasio neutrofil-limfosit sangat berguna untuk membedakan meningitis bakterial dan viral. Peningkatan neutrofil dan penurunan jumlah limfosit merupakan respon imunitas pada inflamasi akut. ${ }^{10}$

Penelitian ini bertujuan untuk membedakan nilai NLR antara meningitis bakterial dan viral pada anak. Dengan adanya perbedaan nilai NLR antara meningitis bakterial dan viral diharapkan pasien dapat dilakukan tatalaksana yang lebih dini untuk mengurangi mortalitas dan morbiditas apabila pemeriksaan cairan serebrospinal tidak memungkinkan untuk dilakukan segera.

\section{Metode}

Rancangan penelitian ini adalah potong lintang dengan pendekatan uji diagnostik. Sampel didapatkan dari data rekam medis pasien meningitis bakterial dan viral usia 1 bulan - 18 tahun yang dirawat di RSUD Dr. Moewardi Januari 2017 - Desember 2020. Besar sampel sebesar 36 pasien. Kriteria inklusi adalah anak usia 1 bulan - 18 tahun dengan gejala klinis meningitis meliputi demam disertai dengan penurunan kesadaran atau tanda rangsang meningeal positif (ubun-ubun besar membonjol, kaku kuduk, tes Kernig positif atau tes Brudzinski positif), kejang tanpa penyebab metabolik, anak dengan hasil analisis LCS dan kultur LCS memenuhi kriteria meningitis bakterial dan viral. Kriteria eksklusi adalah pasien dengan acquaired immunodeficiency syndrome (AIDS), keganasan hematologi, kemoterapi atau radioterapi, penyakit autoimun, trauma kepala, tumor serebri, perdarahan intrakranial, sepsis. Penelitian ini telah memperoleh kelaikan etik dari komisi etik penelitian RSUD Dr. Moewardi Surakarta.

Dilakukan pengambilan data dari rekam medis yang meliputi jenis kelamin, usia, demam, kejang, lama kejang, episode kejang dalam 24 jam, muntah, penurunan kesadaran, tanda rangsang meningeal, paresis saraf kranial, riwayat penggunaan antibiotik, onset pemberian antibiotik, hasil pemeriksaan darah tepi (leukosit, neutrofil, limfosit), hasil analisis LCS (tes Nonne Pandy, protein, glukosa, jumlah sel, jumlah PMN, jumlah MN), kultur LCS, kultur spesimen lain.

Data yang diambil tersebut dimasukkan ke dalam program perangkat lunak SPSS ${ }^{\bullet} 23$. Variabel data kategorik ordinal dilakukan uji Mann Whitney (usia) dan variabel data kategorik nominal dilakukan uji $c h i$ squarel Fisher Exact (jenis kelamin, kejang, penurunan kesadaran, muntah, tanda meningeal, Nonnelpandy, dan infeksi di luar sistem saraf pusat). Variabel dengan data numerik digunakan uji beda independent $t$ test untuk variabel jika berdistribusi normal $(\mathrm{Hb}$, neutrofil, limfosit, glukosa, PMN), sedangkan jika tidak berdistribusi normal menggunakan uji Mann Whitney (GCS, albumin, AT, AL, ANC, ALC, protein, jumlah sel, PMN dan MN). Uji normalitas digunakan uji 
Shapiro wilk. Uji beda NLR berdasarkan hasil diagnosis meningitis viral dan meningitis bakterial mengunakan uji Mann Whitney karena berdasarkan uji Shapiro wilk data tidak memenuhi asumsi normalitas. Tingkat kemaknaan dalam penelitian ini dinyatakan bila $\mathrm{p}<0,05$. Nilai diagnostik NLR untuk memprediksi meningitis bakterial atau viral dianalisis dengan menggunakan kurva ROC, dimana titik potong/cut-off ditentukan nilai spesifisitas dan sensitivitas paling baik.

\section{Hasil}

Subjek penelitian didapatkan 36 data rekam medis yang memenuhi kriteria inklusi. Dari data penelitian didapatkan meningitis viral 15 pasien $(41 \%)$ dan meningitis bakterial 21 pasien (58\%). Meningitis viral $53,3 \%$ terjadi pada usia 1 bulan -1 tahun dan meningitis bakterial 71,4\% terjadi pada usia 1 bulan - 1 tahun. Gejala yang didapatkan pada meningitis meliputi kejang $80 \%$ pada meningitis viral dan $61,9 \%$ pada meningitis bakterial, penurunan kesadaran $66,7 \%$ pada meningitis viral. Infeksi di luar sistem saraf pusat didapatkan pada 18 pasien (50\%) meliputi pneumonia bakterial 56\%, diare akut 17\%, bakteriemia $22 \%$. Dari 36 sampel penelitian, $28 \%$ kultur LCS positif dengan bakteri terbanyak yang ditemukan Staphylococcus haemoliticus. Penggunaan antibiotik sebelum dilakukan pungsi lumbal didapatkan pada 8 pasien (22\%) meliputi 2 pasien $(5 \%)$ diberikan antibiotik $<72$ jam dan 6 pasien $(17 \%)$ yang diberikan antibiotik $>72$ jam sebelum pungsi lumbal. Karakteristik subjek penelitian tertera pada Tabel 1.

Pasien tanpa infeksi di luar SSP dengan meningitis viral mendapatkan hasil pemeriksaan NLR rata-rata $2,10 \pm 1,36$, sedangkan pasien dengan meningitis

Tabel 1. Karakteristik subjek penelitian

\begin{tabular}{|c|c|c|c|}
\hline \multirow[t]{2}{*}{ Variabel } & \multicolumn{2}{|c|}{ Diagnosis (\%) } & \multirow[t]{2}{*}{ p-value } \\
\hline & Meningitis viral & Meningitis bakterial & \\
\hline Usia $^{*}$ & & & 0,36 \\
\hline 1 Bulan - 1 tahun & $8(53,3)$ & $15(71,4)$ & \\
\hline$>1$ tahun -5 tahun & $5(33,3)$ & $3(14,3)$ & \\
\hline$>5$ tahun & $2(13,3)$ & $3(14,3)$ & \\
\hline Jenis kelamin $^{* *}$ & & & 0,65 \\
\hline Lelaki & $9(60,0)$ & $11(52,4)$ & \\
\hline Perempuan & $6(40,0)$ & $10(47,6)$ & \\
\hline Kejang $^{* *}$ & $12(80,0)$ & $13(61,9)$ & 0,29 \\
\hline Lama kejang (menit) ${ }^{* *}$ & & & 0,49 \\
\hline$<15$ & $10(45,5)$ & $12(54,5)$ & \\
\hline$\geq 15$ & $2(66,7)$ & $1(33,3)$ & \\
\hline Episode kejang dalam 24 jam** & & & 0,51 \\
\hline 1 & $4(40,0)$ & $6(60,0)$ & \\
\hline$>1$ & $8(53,3)$ & $7(46,7)$ & \\
\hline Penurunan kesadaran ${ }^{* *}$ & $10(66,7)$ & $8(38,1)$ & 0,09 \\
\hline Muntah $^{* *}$ & $2(13,3)$ & $7(33,3)$ & 0,25 \\
\hline Tanda rangsang meningeal ${ }^{* *}$ & $6(40,0)$ & $3(14,3)$ & 0,12 \\
\hline Nonnelpandy** & $14(93,3)$ & $21(100,0)$ & 0,41 \\
\hline Kultur LCS ${ }^{* *}$ & $0(0,0)$ & $10(47,6)$ & 0,002 \\
\hline Riwayat pemberian antibiotik $^{* *}$ & $5(62,5)$ & $3(37,5)$ & 0,17 \\
\hline Onset pemberian antibiotik ${ }^{* *}$ & & & 0,29 \\
\hline$<72$ jam & $2(28,6)$ & $0(0,0)$ & \\
\hline$>72$ jam & $3(60,0)$ & $2(40,0)$ & \\
\hline
\end{tabular}

Keterangan: *Analisis menggunakan uji Mann Whitney (data ordinal)

** Analisis menggunakan uji chi squarel fhiser exact test (data nominal) 
Ismi Ratnasari dkk: Rasio neutrofil limfosit untuk membedakan meningitis bakterial dan viral pada anak

Tabel 2. Uji beda NLR berdasarkan infeksi di luar SSP

\begin{tabular}{|c|c|c|c|c|}
\hline \multirow[t]{2}{*}{ Variabel } & \multicolumn{2}{|c|}{ Diagnosis } & \multirow{2}{*}{$\begin{array}{c}\text { OR } \\
(95 \% \mathrm{CI}) \\
\end{array}$} & \multirow[t]{2}{*}{ p-value } \\
\hline & Meningitis viral & Meningitis bakterial & & \\
\hline \multicolumn{5}{|l|}{ NLR } \\
\hline Tanpa infeksi di luar SSP a & $2,10 \pm 1,36$ & $4,47 \pm 1,98$ & $11,2(1,1-106,1)$ & $0,01^{*}$ \\
\hline Ada infeksi di luar SSP b & $1,38 \pm 1,02$ & $3,49 \pm 4,78$ & & 0,18 \\
\hline
\end{tabular}

Keterangan : $\mathrm{a}=$ uji independent $t$ test (data numerik berdistribusi normal); $\mathrm{b}=\mathrm{Uji}$ mann whitney (data numerik tidak berdistribusi normal); ${ }^{*}$ signifikan pada $\alpha=5 \%$

Tabel 3. Uji diagnostik NLR terhadap meningitis bakterial

\begin{tabular}{lcccccccc}
\hline AUC & Sensitivity & 1-Specificity & Cut off value & p-value & PPV & NPV & LR+ & LR- \\
\hline 0,83 & 0,81 & 0,28 & 2,31 & 0,02 & $81,8 \%$ & $71,4 \%$ & 2,86 & 0,25 \\
\hline
\end{tabular}

Roc Curve

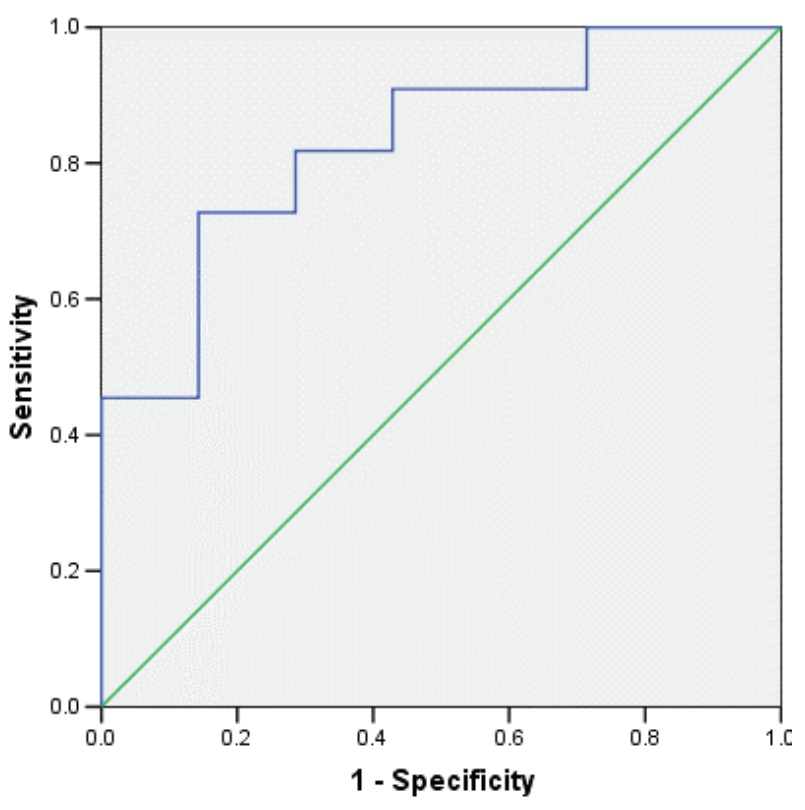

Gambar 1. Kurva ROC NLR terhadap meningitis

bakterial mendapatkan hasil pemeriksaan NLR ratarata $4,47 \pm 1,98$. Hasil Uji statistik mendapatkan nilai $\mathrm{p}=0,01(\mathrm{p}<0,05)$ yang berarti bahwa terdapat perbedaan yang signifikan hasil pemeriksaan NLR antara pasien dengan meningitis viral dan meningitis bakterial pada pasien tanpa infeksi di luar SSP (Tabel 2). Berdasarkan kurva ROC (Gambar 1) didapatkan nilai AUC sebesar 0,83 dengan nilai $\mathrm{p}=0,02(\mathrm{p}<0,05)$. Nilai cut off untuk meningitis bakterial adalah $>2,31$ yaitu pada sensitivitas
$=0,81$ dan 1 -spesifisitas $=0,28$ (spesifisitas $=0,71)$, nilai PPV 81,8\%, NPV 71,4\%, LR+ 2,86, LR- 0,25 (Tabel 3).

\section{Pembahasan}

Angka kejadian meningitis pada neonatus $\pm 300 / 100.000$ anak per tahun, bayi dan balita 2-3 kasus/ 100.000 anak, usia sekolah dan remaja $\pm 1 / 100.000$ anak per tahun. Meningitis bakterial paling banyak terjadi pada usia kurang dari 1 tahun. ${ }^{11,12} \mathrm{Hal}$ ini sesuai dengan hasil penelitian meningitis viral $53,3 \%$ terjadi pada usia 1 bulan -1 tahun dan meningitis bakterial $71,4 \%$ terjadi pada usia 1 bulan -1 tahun dengan patogen bakteri terbanyak yang ditemukan Staphylococcus haemoliticus $(28 \%)$.

Rasio neutrofil-limfosit sangat berguna untuk membedakan meningitis bakterial dan viral. Pemeriksaan cairan serebrospinal merupakan gold standard diagnosis. Pada penelitian ini didapatkan NLR dengan cut off $>2,31$ dapat digunakan sebagai alat diagnostik meningitis bakterial, dengan nilai sensitivitas $81,8 \%$, spesifisitas 71,4\%, PPV 81,8\%, NPV 71,4\%, LR+ 2,86, LR- 0,25. Penelitian Mentis dkk ${ }^{13}$ melaporkan rasio neutrofil limfosit cairan serebrospinal untuk membedakan meningitis viral dan bakterial. Rasio neutrofil limfosit merupakan perbandingan angka neutrofil absolut dengan angka limfosit absolut. Rasio neutrofil limfosit LCS pada meningitis viral lebih rendah, yaitu dengan cut-off 0,4 dan meningitis bakterial dengan cut-off 2 . Nilai rasio neutrofil limfosit darah tepi pada meningitis bakterial memiliki cut off yang lebih 
tinggi dibandingkan nilai rasio neutrofil limfosit LCS, yaitu 8. Nilai sensitivitas dan spesifisitas rasio neutrofil limfosit di LCS sebesar 84,8\% dan 79,6\% dibandingkan di darah sebesar $46,4 \%$ dan $83 \%$.

Pada penelitian Mentis $\mathrm{dkk}^{14}$ dibedakan nilai NLR pada anak usia $>14$ tahun mempunyai nilai sensitivitas dan spesifisitas lebih besar, yaitu $88,5 \%$ dan $89,2 \%$, dengan nilai prediksi positif $89,2 \%$, dan nilai prediksi negatif $88,5 \%$. Penelitian Kim dkk ${ }^{15}$ menunjukkan NLR $\geq 6$ dengan akurasi diagnosis $70,3 \%$ pada hasil cairan serebrospinal negatif. Hal ini menunjukkan bahwa pasien dengan keluhan demam dan nyeri kepala dengan hasil NLR $\geq 6$ pada pemeriksaan darah tepi, klinisi harus mengantisipasi kemungkinan hasil cairan serebrospinal negatif dan mencari penyebab infeksi lainnya.

Penelitian Dogan ${ }^{16}$ membandingkan rasio neutrofil limfosit darah perifer dan pleositosis pada LCS untuk membedakan meningitis viral dan bakterial pada pasien dewasa. Berdasarkan analisis logistik regresi didapatkan hasil bermakna, rasio neutrofil limfosit darah perifer pada meningitis bakterial menunjukkan rasio odds (OR) 0,79 (P<0,05; 95\% CI, 0,98-0,99), dengan nilai cut-off 2,69 dan nilai sensitivitas dan spesifisitas sebesar $86 \%$ dan 91\%. Peningkatan rasio neutrofil limfosit sebanding dengan pleositosis pada LCS yang mencapai $2540 \mathrm{sel} / \mathrm{mm}^{3}$.

Pengambilan sampel darah dan LCS dilakukan sebelum masuk antibiotik karena penggunaan antibiotik menurunkan pleositosis dalam LCS. Penggunaan antibiotik $>72$ jam sebelum dilakukan pungsi lumbal menurunkan jumlah neutrofil, meningkatkan jumlah limfosit, meningkatkan kadar glukosa LCS, menurunkan kadar protein LCS dan memengaruhi hasil kultur LCS. ${ }^{17-20}$ Pada penelitian ini pemberian antibiotik sebelum pungsi lumbal tidak menunjukkan perbedaan bermakna antara pasien dengan meningitis viral dan meningitis bakterial dengan nilai $p>0,05$. Sehingga pemberian antibiotik sebelum dilakukan pungsi lumbal tidak berpengaruh pada nilai NLR pada meningitis viral dan meningitis bakterial.

Penelitian Kim $\mathrm{dkk}^{15}$ menunjukkan bahwa NLR $\geq 6$ dengan akurasi diagnosis $70,3 \%$ pada hasil cairan serebrospinal negatif. Hal ini menunjukkan bahwa pasien dengan keluhan demam dan nyeri kepala dengan hasil NLR $\geq 6$ pada pemeriksaan darah tepi, klinisi harus mengantisipasi kemungkinan hasil cairan serebrospinal negatif dan mencari penyebab infeksi lainnya. Pada penelitian ini, pasien yang disertai infeksi di luar SSP dengan meningitis viral mendapatkan hasil pemeriksaan NLR rata-rata $1,38 \pm 1,02$, sedangkan pasien dengan meningitis bakterial mendapatkan hasil pemeriksaan NLR rata-rata 3,49 44,78. Hasil pemeriksaan NLR tidak terdapat perbedaan bermakna antara pasien dengan meningitis viral dan meningitis bakterial pada pasien dengan infeksi di luar SSP.

Pasien tanpa infeksi di luar SSP dengan meningitis viral mendapatkan hasil pemeriksaan NLR rata-rata $2,10 \pm 1,36$, sedangkan pasien dengan meningitis bakterial mendapatkan hasil pemeriksaan NLR rata-rata $4,47 \pm 1,98$. Hasil pemeriksaan NLR terdapat perbedaan bermakna antara pasien dengan meningitis viral dan meningitis bakterial pada pasien tanpa infeksi di luar SSP. Berdasarkan uraian di atas maka dapat diketahui bahwa NLR dapat digunakan sebagai prediktor meningitis viral dan bakterial pada pasien meningitis yang tidak disertai infeksi di luar SSP.

Rasio neutrofil limfosit adalah parameter sederhana yang dapat digunakan untuk membedakan meningitis bakterial dan viral dengan ketersediaannya yang luas di rumah sakit dan harga terjangkau. Dengan demikian diharapkan hasil penelitian yang diperoleh dapat digunakan untuk membedakan meningitis bakterial dan viral lebih dini sehingga dapat dilakukan tatalaksana segera di rumah sakit bila tidak memungkinkan dilakukan pungsi lumbal.

Penelitian kami memiliki keterbatasan, yaitu penelitian dilakukan secara retrospektif dan terdapat keterbatasan pada pengumpulan data yang hanya menyertakan parameter objektif dalam rekam medis. Untuk itu, perlu dilakukan penelitian lanjutan dengan jumlah sampel yang lebih banyak dengan desain prospektif dan mengendalikan faktor perancu.

\section{Kesimpulan}

Rasio neutrofil limfosit dapat digunakan untuk membedakan meningitis bakterial dan viral dengan nilai cut off untuk meningitis bakterial adalah $>2,31$. Nilai NLR tersebut dapat digunakan untuk diagnosis dini meningitis bakterial sehingga tatalaksana dapat diberikan lebih dini, mortalitas dan morbiditas menurun. 


\section{Daftar pustaka}

1. Van de Beek D, Cabellos C, Dzupova O, dkk. ESCMID guideline: Diagnosis and treatment of acute bacterial meningitis. Clin Microbiol Infect 2016;22:S37-62.

2. Ku LC, Boggess KA, Cohen W. Bacterial meningitis in infants. Clin Perinatol 2015;42:29-45.

3. Saha S, Sharma J, Chowdrury M, Alauddin M. Change of protein content in cerebrospinal fluid (CSF) with the different types of meningitis. Int J Cur Res Rev 2016;8:16-20.

4. Prober CG, Srinivas NS, Mathew R. Central nervous system infections. Dalam: Kliegman R, Stanton B, St. Geme JW, Schor NF, Behrman RE, Nelson WE, penyunting. Nelson textbook of pediatrics. Edisi ke-20. Philadelphia: Elsevier; 2016. h. 2936-46.

5. Sáez-llorens X, Jr GHM. Bacterial meningitis in children. Lancet 2003;361:2139-48.

6. Urrechaga E, Bóveda O, Aguirre U, García S, Pulido E. Neutrophil cell population data biomarkers for acute bacterial infection. J pathol infect dis 2018;1:1-7.

7. Gurol G, Ciftci IH, Terzi HA, Atasoy AR, Ozbek A, Koroglu M. Are there standardized cutoff values for neutrophil lymphocyte ratios in bacteremia or sepsis? J Microbiol Biotechnol 2015;25:521-5.

8. Forget P, Khalifa C, Defour JP, Latinne D, Pel MC Van. What is the normal value of the neutrophil - to - lymphocyte ratio ? BMC Res Notes 2017;10:10-3.

9. Demirer, Guragac Z. The neutrophil-to-lymphocyte ratio in clinical practice. Can Urol Assoc J 2016;10:141-2.

10. Kutlu A, Bınıcı N. Does increased neutrophillymphocyte ratio predict autism spectrum disorder? Anadolu Psikiyatr Derg 2018;19:607-14.

11. Agyeman P, Grandgirard D, Leib SL. Neuroinflammation in bacterial meningitis. Dalam: Lyck R, Enzmann G, penyunting.
The blood brain barrier and inflammation. Switzerland: Springer International Publishing; 2017.h.213-52.

12. Herini ES, Triono A. Bacterial meningeal score (BMS) sebagai indikator diagnosis meningitis bakterialis di RSUP Dr. Sardjito Yogyakarta. Sari Pediatri 2014;15:247-79.

13. Mentis A, Kyprianou M, Xirogianni A, Kesanopoulos K, Tzanakaki G. Neutrophil to lymphocyte ratio in the differential diagnosis of acute bacterial meningitis. Eur J Clin Microbiol Infect Dis 2016;35:397-403.

14. Mentis AA, Kyprianou MA, Tzanakaki G. Agespecific application of neutrophil-to-lymphocyte ratio in meningitis: a nationwide study. Eur J Clin Microbiol Infect Dis CSF 2017;36:1553-7.

15. Kim JH, Kim HJ, Na JU, Han SK, Choi PC, Shin DH. Hematologic parameters to predict negative cerebrospinal fluid examination results among neurologically intact patients who underwent lumbar puncture on suspicion of central nervous system infection. Clin Exp Emerg Med 2017;4:25-31.

16. Dogan M. Evaluation of neutrophil-to-lymphocyte ratio in adult bacterial meningitis cases in line with the literature. Merit Res J 2019;7:389-93.

17. Rogers T, Sok K, Erickson T, dkk. Impact of antibiotic therapy in the microbiological yield of healthcare - associated ventriculitis and meningitis. Open Forum Infect Dis 2019;1-4.

18. Adhikari S, Gauchan E, BK G, Rao K. Effect of antibiotic pretreatment on cerebrospinal fluid profiles of children with acute bacterial meningitis. Nepal J Med Sci 2013;2:135-9.

19. Nigrovic LE, Malley R, Macias CG, Kanegaye JT, Morosutherland DM. Effect of antibiotic pretreatment on cerebrospinal fluid profiles of children with bacterial meningitis. Pediatrics 2021;122:726-30.

20. Alam A. Kejadian meningitis bakterial pada anak usia 6-18 bulan yang menderita kejang demam pertama. Sari Pediatri 2011;13:293-8. 